\title{
強誘電性液晶の過渡光散乱を利用する高速光 スイッチ素子の特性と液晶材料依存性
}

$\begin{array}{llllll}\text { 正員 } & \text { 尾 } \text { 崎 } & \text { 雅 } & \text { 則 } & \text { (大阪大) } \\ \text { 非会員 } & \text { 岸 } & \text { 尾 } & \text { 伸 } & \text { (大阪大) } \\ \text { 正 員 吉 } & \text { 野 } & \text { 勝 } & \text { 美 } & \text { (大阪大) }\end{array}$

\section{1. まえがき}

近年, TN (Twisted Nematic) 形, DSM (Dynamic Scattering Mode) 形, GH (Guest Host) 形などのネ マチック波晶を用いる表示素子が開発され，広く使わ れている。しかしながら，これらのネマチック液晶素 子は, 応答速度か数 $\mathrm{m}$ 数十 ms. と極好遅いという 共通の欠点をもっており，応用範囲も限られてくる。 てれは，主に基本となる駆動力として誘電率の異方性 に基つくくルクを利用しているためである。

一方, 1975 年に Meyer 氏らにより强誘電性液晶が 開発され(1)，乙れを利用した新しいタイプの表示素子 が種々提案されている。第 1 のタイプは，吉野氏らに より提案されたすので(2), 強誘電性液晶特有のへリカ ル構造を利用したものである。すなわち，比較的厚い セル $(>10 \mu \mathrm{m})$ 亿おいて, 強誘電性液晶はカイラル・ スメクチック相 $\left(\mathrm{Sm}^{*}\right.$ 相) でヘリカル構造をとり，局 所的な屈折率のゆらぎのために光散乱が生じる。とて ろが，こてで電界を印加するととによりへリカル構造 が消失し，光散乱が減少して光の透過度が上がる現象 を利用するすのである。しかし，乙の方式の電界に対 する応答は比較的遅い。乙れは，へリカル構造におい て双極子モーメントがマクロには相殺し合い，正味の 自発分極が現われないため，電界による十分なトルク が発生しないためである。

第 2 のイプは，N. Clark 氏らにより提案された 6ので ${ }^{(3)}, 1 \sim 2 \mu \mathrm{m}$ 程度の薄いセルを偏光子の間に置 く方法である。すなわち，壁面により強制された配向 を電界住自発分極の反転を利用して再配向させ， それに伴って光学軸の方向が変化することを利用する あのである。とこでは，乙れを SSFLC (Surface Sta*

Characteristics of a High Speed Optical Switching Element Utiling Crystals and Its Material Dependent. By Masanori Ozaki, Member, Shin-ichi Kishio, Non-member \& Katsumi Yoshino, Member (Faculty of Engineering, Osaka University)

星䗁雅則: 正员, 大陑大学工学部

岸尾伸一: 非会冒, 大阪大学工学部

志野勝美：正員，大服大学工学部 bilized Ferroelectric Liquid Crystal) 形素子と呼ふ心。 この方式は，高速ではあるが，大面積にわたる良好な ホモジニアス配向がかなり難しいとと, 更にコントラ ストが比較的低く，偏光子を用いているため視角特性 ああまり良くないなどの問題点を抱えている。前者に ついてはネマチック液晶で串用されているポリマーコ ーティングとラビング技術の導入などでかなり改善さ れたがままだ十十分とは言えない。

第3のタイプは，最近，我々が提案したもので，印 加電界の極性反転による自発分極反転時の分子再配 向に伴う過渡的な光散乱を利用するすので，TSM (Transient Scattering Mode) 形と名付けるあのであ $ろ^{(4)(5)}$ 。乙の TSM 素子は, ヘリカル構造があらかじ め解けて自発分極がそろっているため応答速度が $\mu \mathrm{s}$ のオーダと極めて高速である。また，高いコントラス 卜が得られ，偏光子や特殊な配向技術を一切必要とし ないなどの利点を持っている。

TSM 素子に関するこれまでの報告では，強誘電 性液晶として最む広く研究されている DOBAMBC (decyloxy benzylidene-p'-amino-2-methylbutylcinnamate) を用いて，応答速度の高速性と高いコントラ ストを示すことを述べた。本論文では，種々の強誘電 性液晶を用いた TSM 素子の応答速度およびニントラ ストを調へ，更に透過光量の立下り，すなわち，過渡 的な散乱によって透過光量が減少した後に，元の高透 過状態に㞍るまでの時間についても検討する。

強誘電性の表示素子では，高透過状態を維持するた めに，直流バイアス電圧を印加して双極子モーメント の方向をそろえておく必要がある場合がある。しかし バイアス電王として直流電卧を印加すると，イオン電 流に伴う電力損失が大きくなり，更には液晶の劣化に あつながる。そこで，これを避りるために繰り返しパ ルス電圧を印加することによって高透過状態を得るこ とを考案したが，表示素子実用の場合に有效であるこ とを明らかにしたので，てのととについても述へる。 


\section{2. 試料および実験方法}

実験江用いた強誘電性液晶は DOBAMBC, DOBA一 1-MPC, DOBA-1-MBC, DOBA-1-MPenC である。 図1にこれらの分子構造および正式名称を示す。合成 法，および電気的性質については既化報告した ${ }^{(6)(7) 。}$ 表 1 は, これらの液晶の自発分極の最大值であり, DOBAMBC に比へて他の液晶の自発分極が著しく大 きいととが加る(8)。セルは，2枚の透明電極（ネサ ガラス）をスペーサを用いて適当な電極間距離を保つ ように対向させ、スペーサとしては，ポリエチレンテレ フタレート(PET)のシートを用いた。ネサガラスの表 面は，ネマチック液晶でホモジニアス配向を得る目的 で行われているの之同様に，綿布で一方向敒るいわ ゆるラビング処理を施した。構成したセルに，毛細管 現象を利用して強誘電性液晶を注入して素子とした。 图 2 亿示すようにセルを $\mathrm{He}-\mathrm{Ne}$ レーザ光 $(6328 \AA)$
表 1 各種強誘電性液晶の自発分極 Table 1. Spontaneous polarizations of various ferroelectric liquid crystal.

\begin{tabular}{|c|c|c|c|}
\hline 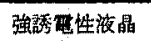 & DOBAMBC & DOBA.1-MPC & DOBA-1I-MBC \\
\hline $\begin{array}{l}\text { 自發分梧 } \\
P_{s}\left(\mathrm{nc} / \mathrm{cm}^{2}\right)\end{array}$ & 2 & 18 & 42 \\
\hline
\end{tabular}

の光路上に置き，透過光を光電子増倍管で受光し，電 壬印加に伴う透過光量の変化を観測した。なお，㻞光 子は一切用いていない。

コントラストの定義としては，透過状態（ヘリカル 構造の解けた状態）と暗状態（散乱状態）との透過光 量の比を用い，立上り時間は，印加電圧反転時から全 透過光量変化の $90 \%$ に達するまでの時間とした。

\section{3. 結果および検討}

〈3.1) TSM 形電気光学効果 DOBAMBC 100 $\mu \mathrm{m}$ 七ルに図 3（a）に示すような，極性反転ステップ 電圧を印加した場合の透過光量の変化 を図 3 (b) に示す。極性反転時に強い 光散乱に伴って透過光量が大幅に減少 していることがわかる。

この TSM 現象は, 印加電界の極性 反転時に見られる過渡的なすのであ る。しかし，いったん極性を反転した 後、散乱が収まる前汇再び極性を反転 させると，散乱状態つまり暗状態は持

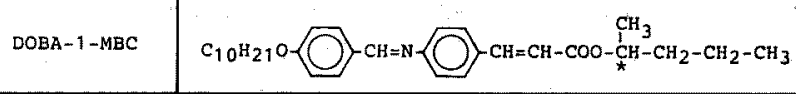

p-decyloxybenzylidene-p'-amino-1-methylbutylcinnamate DOBA-1-KPenc $\mathrm{C}_{10} \mathrm{H}_{21} \mathrm{O} \bigcirc-\mathrm{CH}=\mathrm{N} \longrightarrow-\mathrm{CH}=\mathrm{CH}-\mathrm{COO}-\mathrm{CH}_{x}^{\mathrm{CH}}-\mathrm{CH}_{2}-\mathrm{CH}_{2}-\mathrm{CH}_{2}-\mathrm{CH}_{3}$ p-decyloxybenzylidene-p'-amino-1-methyl pentylcinnamate

図 1 今回の実験に用いた強誘電性液晶の分子構造と名称

Fig. 1. Molecular structure of ferroelectric liquid crystal used in this experiment and their abbreviated names.

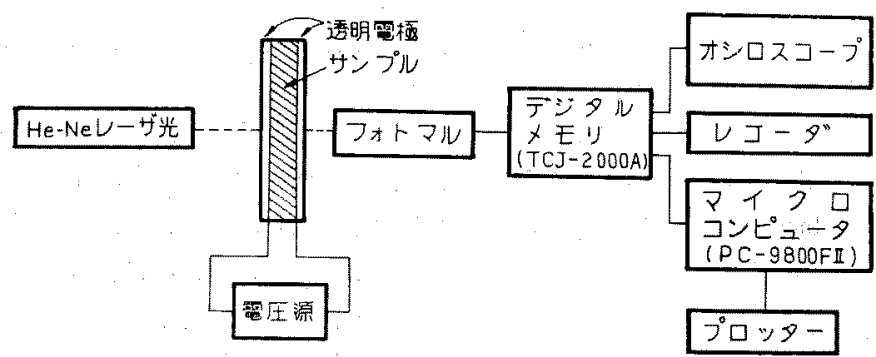

因 2 電気光学效果の測定に用いた測定系

Fig. 2. Experimental set-up for the measurement of electro-optic effect.

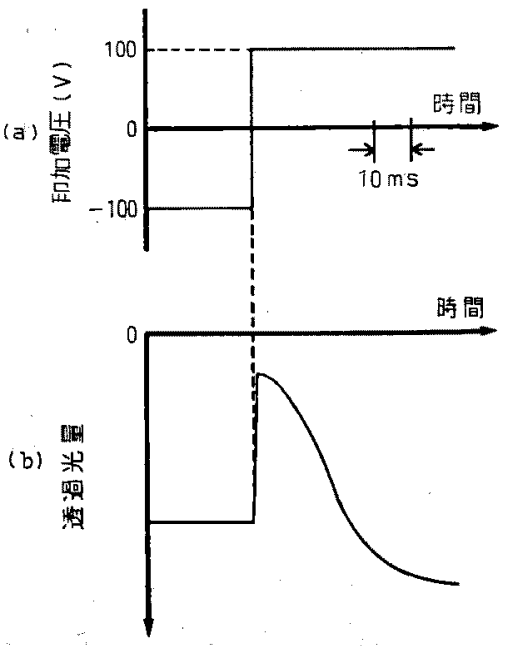

(a) 矂加電压波形

(b) He-Ne レーザ光の透迵置変化

図 3 DOBAMBC $100 \mu \mathrm{m}$ セルにおり る 1 回極性反転による透過光量変化

Fig. 3. Response to single step wise polarity reversal of voltage applied to $100 \mu \mathrm{m}$ cell of DOBAMBC. 
(a)

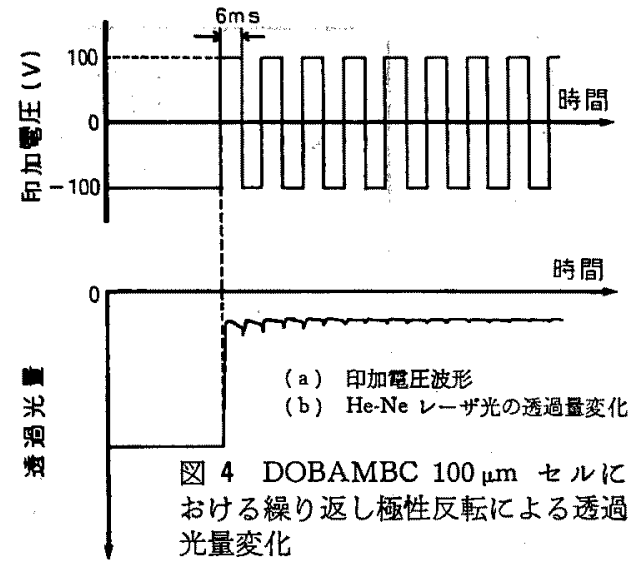

Fig. 4. Response to the repeated polarity reversals of voltage applied to $100 \mu \mathrm{m}$ cell of DOBAMBC.

続される。こうした操作を繰り返すことによって，図 4 亿示すように暗状態を任意時間持続させるととが可 能であることがわかる。

〈3.2〉TSM 形素子の立上り時間 図 5 は, DOBAMBC $100 \mu \mathrm{m}, 50 \mu \mathrm{m}$ および $25 \mu \mathrm{m}$ セルにおけ る立上り時閶の電圧依存性である。どれる用加電圧の

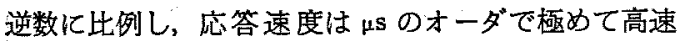
であるるこのととは，TN 素子が誘電率の異方性に基 ふく力を駆動力としているため，立上り時間が $E^{2}$ に 反比例するのに対して，TSM 素子は目発分極 $P s k$ 起因するトルク $P: E$ を駆動力としているととを示し ている。また，逆分極ドメインの核生成と成長という

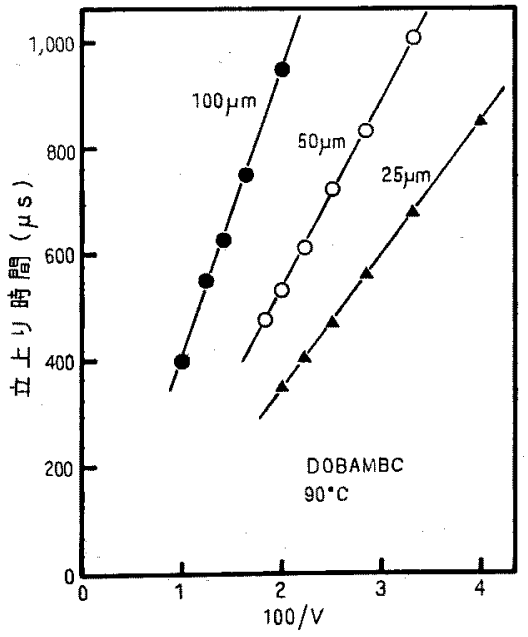

図 5 DOBAMBC $25 \mu \mathrm{m}, 50 \mu \mathrm{m}, 100 \mu \mathrm{m}$ 七ル における立上り時間の電圧依存性

Fig. 5. Dependence of rise times on the reciprocal of applied voltage in $25 \mu \mathrm{m}$, $50 \mu \mathrm{m}$ and $100 \mu \mathrm{m}$ cells of DOBAMBC.

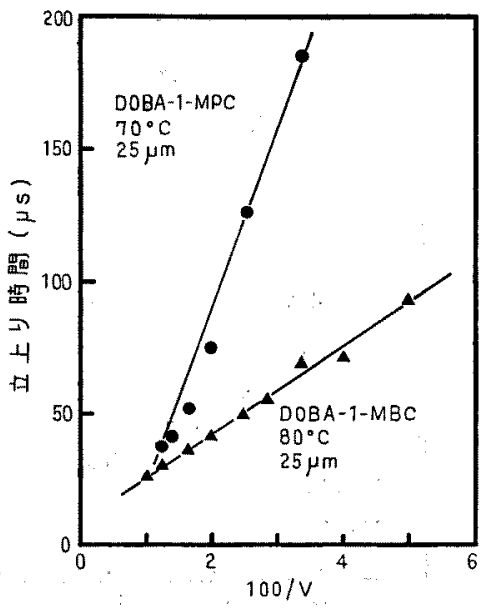

図 6 DOBA-1-MPC, DOBA-1-MBC の $25 \mu \mathrm{m}$ セルにおける立上り時間の電圧依存性

Fig. 6. Dependence of rise times on the reciprocal of applied voltage in $25 \mu \mathrm{m}$ cells of DOBA-1-MPC and DOBA-1-MBC.

観点からあ考察する必要があると思われるが，現在の 段階では，その詳細は不明である。

TSM 素子は， $P_{s} \cdot E$ を駆動力としているてとから， 大き登発分極 $P_{s}$ を持つ強誘電性液晶を用いれば, 更 亿高速な応答が実現できると考えられる。DOBAMBC $\left(P_{s}: 2 \mathrm{nC} / \mathrm{cm}^{2}\right)$ K比べて自発分極の大きな DOBA-1$\mathrm{MPC}\left(P_{s}: 18 \mathrm{nC} / \mathrm{cm}^{2}\right)$ および DOBA-1-MBC $\left(P_{s}:\right.$ $\left.42 \mathrm{nC} / \mathrm{cm}^{2}\right)^{(8)}$ に於ける立上り時間の電圧依存性を図 6 に示す。どちらす DOBAMBC と同様に，印加電王 の逆数に比例し，立上り時間が速くなっている。特に DOBAMBC に比べて自発分極が一析以上も大きな DOBA-1-MBC では, 一析以上も高速である。

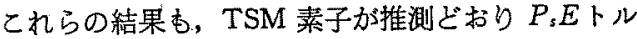
クを駆動力としており，立上り時間 $T_{\mathrm{s}}$ が $T_{\mathrm{s}} \sim \eta / P_{\mathrm{s}}$ 。 $E(\eta:$ スメクチック層内での分子の首振り運動に関す る粘性係数）の関係を満していることと一致する。

図 7 は DOBAMBC 亿おりる立上り時間の温度依 存性である。温度に大きく依存し，高温ほど応答時間 が短くなっている。温度の上昇に伴って $\eta$ および P は，どちらす減少するが，ての場合は，上に述へたた $T_{s} \sim \eta / P_{s} \cdot E$ の関係が成立している中で， $\eta$ の温度依 存性の方が支配的であると考えられる。

〈3.3〉TSM 形素子のコントラスト

図8は, DOBAMBC のコントラストの電王依存性である。ど ちらあ従来のネマチック液晶を用いた素子や SSFLC 形素子に比べて極めて高いコントラストを示してい る。また，TSM 素子が光の散乱を利用しているてと 


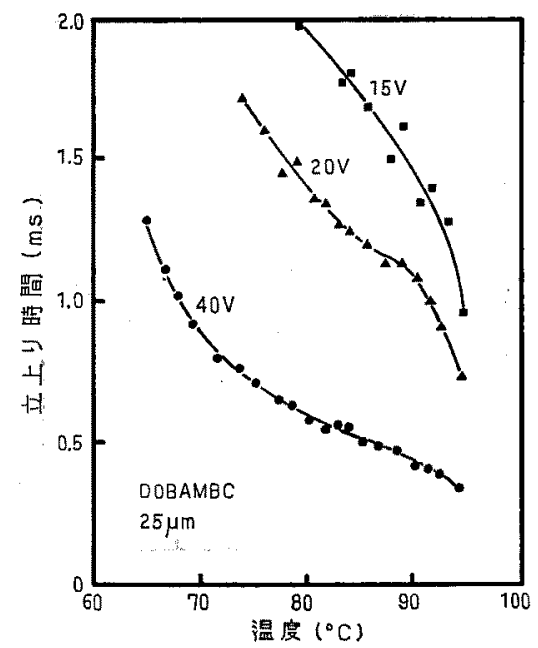

図 7 DOBAMBC $25 \mu \mathrm{m}$ 七ルにおりる 立上り時間の温度依存性

Fig. 7. Temperature dependence of rise time of the DOBAMBC cell with $25 \mu \mathrm{m}$ thickness.

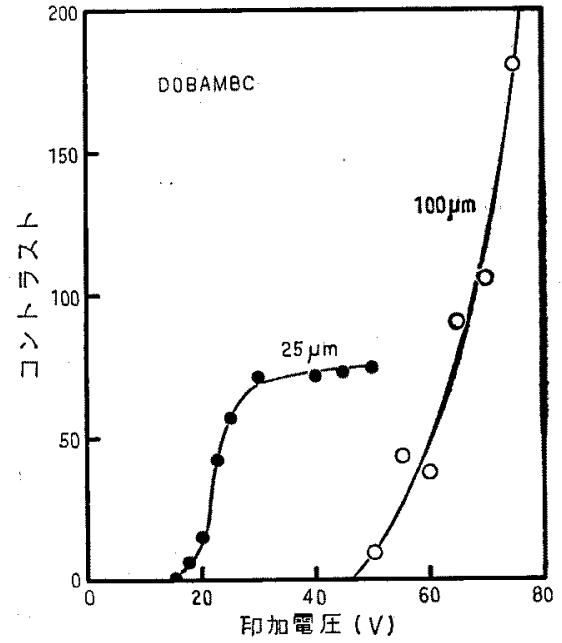

図 8 DOBAMBC $25 \mu \mathrm{m}, 100 \mu \mathrm{m}$ セルに おけるコントラストの電圧依存性

Fig. 8. Voltage dependence of contrast of transmission light through the $25 \mu \mathrm{m}$ and $100 \mu \mathrm{m}$ cell of DOBAMBC.

から，七ル厚が厚いほどコントラストが大きいことも

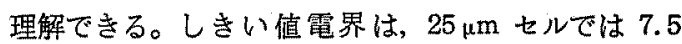
$\mathrm{kV} / \mathrm{cm}, 100 \mu \mathrm{m}$ セルでは $5 \mathrm{kV} / \mathrm{cm}$ とセル厚が厚い方 が低くなっている。これは，薄い方が壁面の影響を強 く受けているためと考えられる。

DOBAMBC におけるコントラストの温度依存性を 図9に示す。低温側ほどコントラストは大きくなって いる。乙れには，複数のファクターが関係しているす のと考えられ，現段階でははっきりした原因は不明で

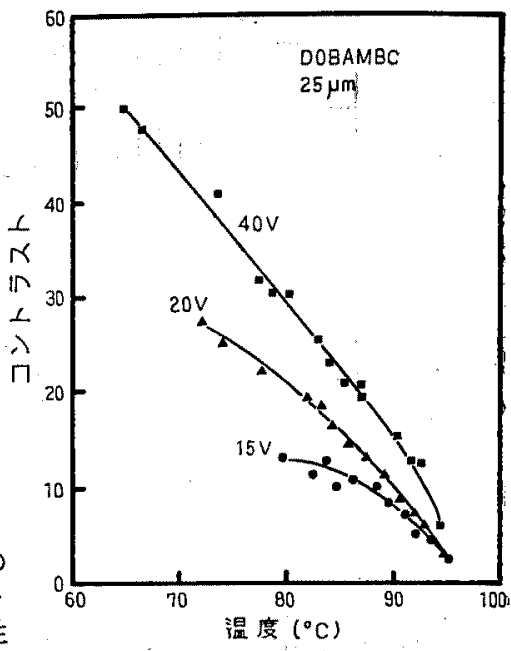

Fig. 9. Temperature dependence of contrast of transmission light through the $25 \mu \mathrm{m}$ cell of DOBAMBC:

\section{図 10}

DOBAMBC

$50 \mu \mathrm{m}$ セルの コントラスト の配向度依存 性

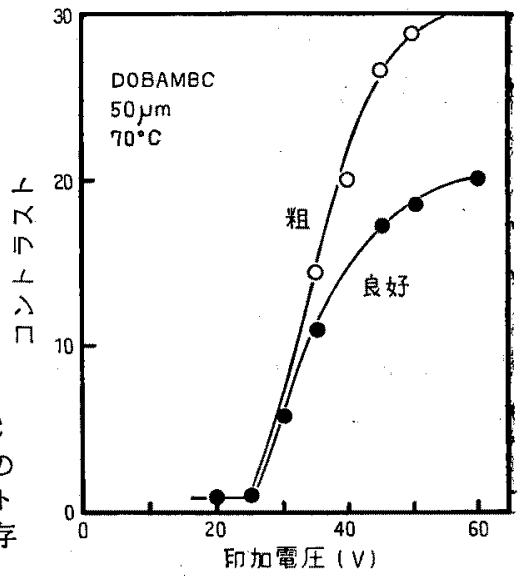

Fig. 10. Dependence of contrast of transmission light through the $50 \mu \mathrm{m}$ cell of DOBAMBC on the degree of molecular alignment.

あるが，一つには，チルト角の温度依存性の効果が考 えられる。すなわち，チルト角が温度の降下と共に增 大し(9)，それ伴って屈折率の翼方性6大きくなり， 電界を反転したときの分子の激しい運動に伴う届折率 のゆらぎが大きくなる。その結果，光散乱か增大する ためであると考えられる。また，その他にあ温度降下 に伴う $P_{s}$ の增大に上って, 空間的に逆分極ドメイン の核生成密度が増加し, 光学的不均一性が増大した可 能性屯考えられ得る。

図 10 は液晶の配向状態のコントラストに対する影 響を示したあのである。この際，良好な配向を得るた めに $10 \mathrm{kG}$ の磁界中で Isotropic 相から SmA 相に 
かけて $10^{\circ} \mathrm{C} / \mathrm{h}$ の割合で徐冷した ${ }^{(10)}$ 。それに対して。 粗い配向は磁場を印加しないで $120^{\circ} \mathrm{C} / \mathrm{h}$ の割合で Iso tropic 相から $S_{\mathrm{m}}$ 相まで降温した。明らかに配向の良 いセルより悪いセルの方がコントラストが良い。ただ し，立上り時間には変化は見られない。つまり，TSM 形電気光学勃果を用いた素子では, 配向に注意を払う 必要がなくセル作製が容易であるといえる。

〈3.4〉 TSM 形素子の立下り時間 電気光学効果 を表示素子として応用する際に，立上り時間，コント ラストと並んで立下り時間あ重要な要因である。すな わち，TSM 素子の場合の暗状態加ら明状態へのスイ ッチングである。前に示した図 3 (b)加らわかるよう 飞, DOBAMBC では立下り時間が立上り時間に比べ てかなり遅い。困 11 は立下り時間の電圧依存性であ る。電圧の增加に伴い速い立下り時間を示すが，立上 りの場合のように完全に $1 / V$ の゙ララフに乗らない。 温度依存性は，高温側ほど立下り時間が短くなってい る。

DOBA-1-MPC および DOBA-1-MBC の立下り時 間の電王依存性を図 12 亿示す。DOBAMBC に比へ 非常に速い立下り時間を示している。DOBA-1-MPC, DOBA-1-MBC などでは, 図 13 に示すように誘電率 の分散周波数は極めて高い( ${ }^{(8)}$ 。乙こで測定している誘 電率はヘリカル構造の捠れ運動に対応するもの之考え られるが，このように分散周波数が分子構造の若千の

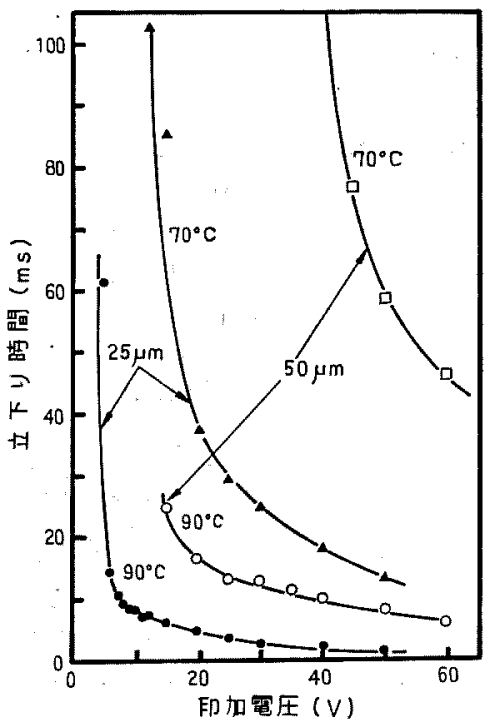

図 11 DOBAMBC $25 \mu \mathrm{m}, 50 \mu \mathrm{m}$ セルの 立下り時間の電圧依存性

Fig. 11. Voltage dependence of decay time of "DOBAMBC cells with $25 \mu \mathrm{m}$ and $50 \mu \mathrm{m}$ thickness.

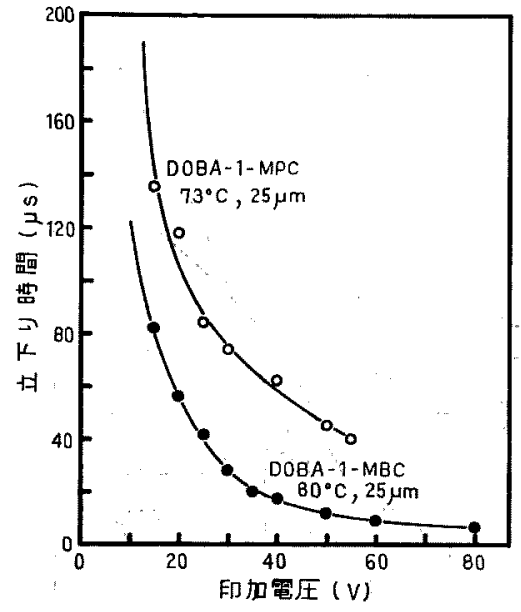

図 12 DOBA-1-MPC, DOBA-1-MBC $25 \mu \mathrm{m}$ セルにおりる立下り時間の電圧传存性

Fig. 12. Voltage dependence of decay time of DOBA-1-MPC and DOBA-1-MBC cells with $25 \mu \mathrm{m}$ thickness.

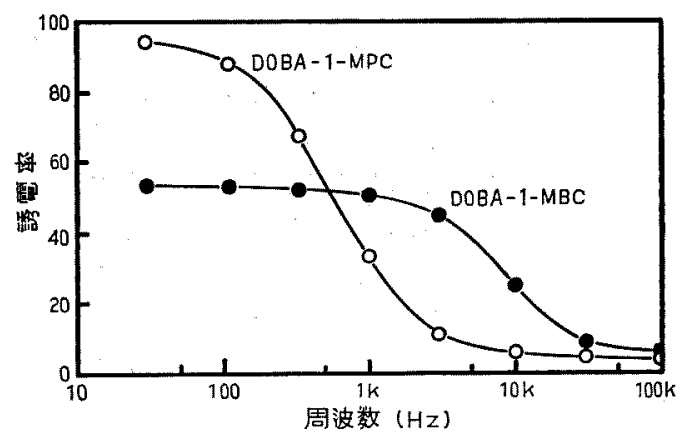

図 13 DOBA-1-MPC, DOBA-1-MBC の 誘電率の周波数分散

Fig. 13. Frequency dependence of dielectric constants of DOBA-1-MPC and DOBA-1MBC.

違いに，大きく影響を受ける理由は明らかではない。し かし，乙れらの分散周波数の高い物質が DOBAMBC に比へて，遥かに速い立下り時間を示すことは，ての 減衰過程が分散周波数, すなわち, ヘリカル構造の運 動に多少関係しているてとを示唆している。言換える 之, 電界による一様な配向が反転する過程で, ヘリカ ル構造の特性を若干反映している可能性があるが, 詳 紐は明らかではない。

ところで, 図14 からあわかるように，セル厚が薄い 方が立下り時間は短くなっている。このセル厚依存強 く受りているすのと考えられる。すなわち, 電界の反転 により再配向された際の過渡的な液晶分子の乱れが, セル厚が薄いほど壁面の拘束力によって安定化しやす 


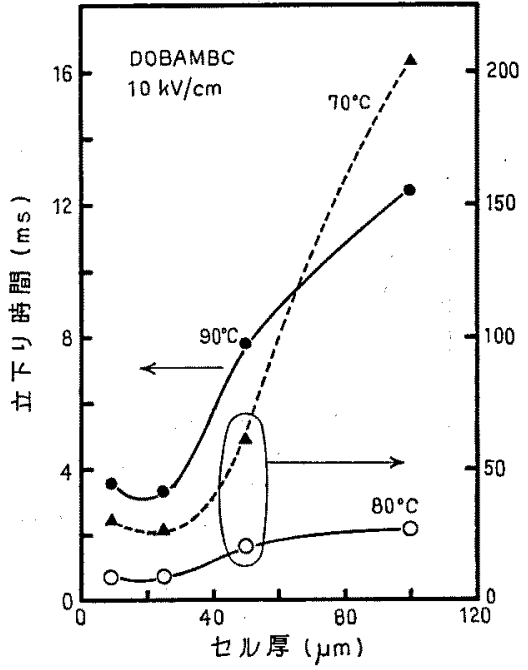

図 14 DOBAMBC の立下り時間の七ル厚依存性

Fig. 14. Dependence of decay time of $D O B A M B C$ at various temperature on cell thickness.

くなっているあのと考えられる。このように立下り時 間は分子運動そのあのの本質的な特性の他に, 種々の 外的因子の影響を大きく受けていると考えられる。

〈3.5〉 パルス駆動による高光透過状態の維持

厚いセルの強誘電性液晶で高光透過状龍（明状 態）を得るためには，バイアス電圧を印加してへ リカル構造を解く必要がある。しかし, バイアス 電圧として直流電圧を印加すると，イオン電流に 伴う電力損失が大きくなり，また，液晶の劣化に あつながる。これを避りるだめに，繰り返しパル ス電圧を印加することによって高光透過状態を得 るととを考えた。すなわち、へリカル構造の解け た状態加らへカル構造に自然に復㷌するのには かなり長い繥和時間を要するので，その時間内で 適当なタイミングでパルス電圧を印加すれば，復 㫶が抑制されヘリカル構造の解けた高光透過状態 が長時間維持されることになる。特にへリカル構造の 解けた状態では自発分極 $P$ s が現われているので，電 界 $E$ 印加に上るトルク $P_{s} E$ は大きく、へリカル構 造を巻いた状態からへリカル構造を解くのに要する電 界に比べて，低い電界でヘリカル構造の解けた状態を 維持できるもの上考元られる。

図 15 は，直流電圧を印加してヘリカル構造が解け た高光透過状態から，パルス電圧に切り换えたときの 透過光量の変化を示したすのである。ここで，パルス 波高值 $V_{D}$ は, 直流電圧と同じであり, パルス間隔 $T_{d}$ はどちらも $10 \mathrm{~ms}$ である。(a)は, パルス幅 $T_{p}$

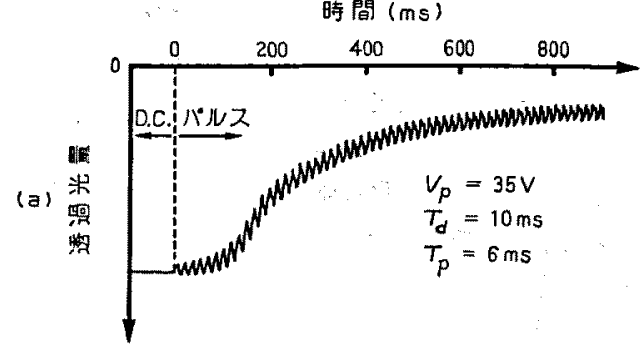

時開 (ms)

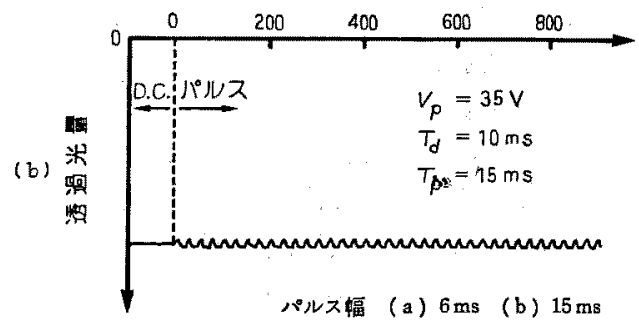

図 15 DOBAMBC $25 \mu \mathrm{m}$ セルにおりる連続 パルス印加による高光透過状態

Fig. 15. Transmission of transparent state through $25 \mu \mathrm{m}$ cell of DOBAMBC under the application of pulse trains.

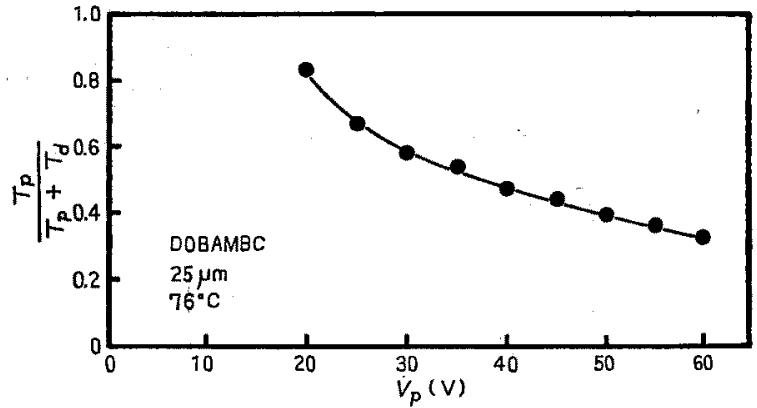

図 16 DOBAMBC $25 \mu \mathrm{m}$ セルにおいて高光透過状態 を維持するのに必要な $T_{p} /\left(T_{p}+T_{d}\right)$ 值

Fig. 16. Voltage dependence of the ratio $T_{p} /\left(T_{p}+T_{d}\right)$ to keep transparent state in the DOBAMBC with $25 \mu \mathrm{m}$ thickness.

$=6 \mathrm{~ms}$ で, 透過光量は次第に減少し, 高光透過状態 は実現できない。とれに対して，パルス幅 $T_{p}$ を 6.5 $\mathrm{ms}$ 以上之する之高光透過状態加保持され，(b)虫， $T_{p}=15 \mathrm{~ms}$ で高光透過状態が維持されている様子を 示したものである。とのように，パルス間隔 $T_{d}$ とパ ルス幅 $T$ 学うまく調整することによって，高光透過 状態つまりへリカル構造の解けた状態を維持するとと が可能であるととがわかる。

上に述べたように直流バイアスからパルス電圧に切 替えて高光透過状態を維持するために必要なパルス幅 およびパルス間隔は，温度，七ル厚，パルス波高值な 
(a)

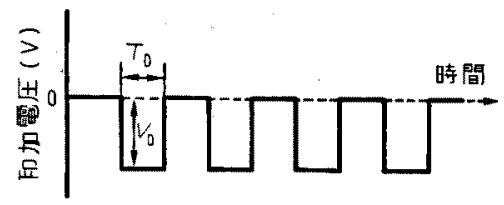

(b)

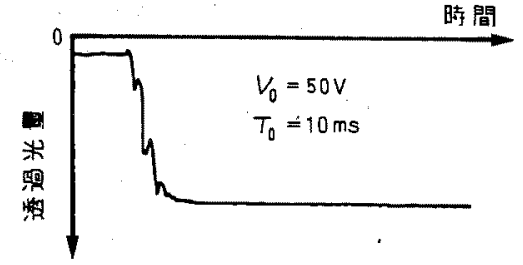

図 17 DOBAMBC $25 \mu \mathrm{m}$ 七ルにおりる 連続パルス電圧印加による透過光量変化

Fig. 17. Transmission change of DOBAMBCcell with $25 \mu \mathrm{m}$ thickness under the application of pulse trains.

どに依存している。図 16 は，パルス間隔 $T_{d}$ を一定 とした場合に高光透過状態を維持するために必要な,

最小の $T_{p} / T_{p}+T_{d}$ 比之, パルス波高值 $V_{p}$ との関係 を示す。すなわち，この比が小さいほど実用的には有 利であるといえる。てれを見ると高光透過状態を維持 するために必要な臨界パルス幅は，パルス波高值が高 くなるはど小さいととがわかる。乙れは，分子を配向 させるためのトルクが $P_{s} ・ E$ であり, 電界に比例して その運動の応答が速いことからも理解できる。

あらかじめ, 直流電圧を印加するのではなく, 初め 功パルス電压を印加した場合の透過光量の変化を考 える。図 17(a) が甲加パルス波形で，(b)加透過光 量の変化である。図から明らかなように，あらかじめ 直流電圧を印加するのではなく，パルス電圧のみであ 高光透過状態が害現できることがわかる。すなわち， パルスのオン時，オフ時での液晶分子の応答時間が異 なり，オン時の方が速いため，パルス波高值がある值 以上であれば，時間の経過と共に次第に高光透過状態 となりその状態が保持される。

ところが，パルス電圧のみで高光透過状態を実現す るには，かなり高いパルス波高值 $V_{p}$ を必要とする。 過状態を維持するよりも高い電生を必要とする。これ は初めの状態で，液晶分子がヘリカル構造を取ってお り自発分極がマク口的には現われていないため, $P_{s} \cdot E$ トルクが有効に使われないいためである。

そこで, 図 18(a) に示すように，あらかじめへリ カル構造を解くのに十分な直流電圧 $V_{0}$ を四加して, いったんへリカル構造を解いておき，次にそれよりあ 低いパル波高值 $V_{p}$ で駆動するような方法を考え る。との駆動方法と、パルス波形のみによる駆動方法 (a)

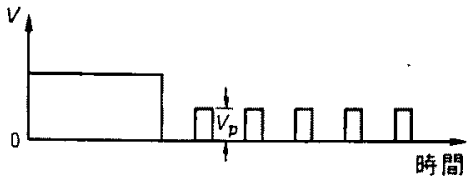

(b)

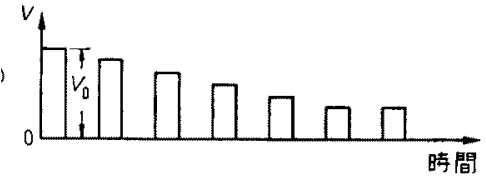

(c)

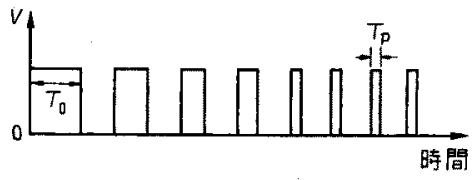

因 18 高光透過状態の維持に用いる様々な 印加パルス䉓圧波形

Fig. 18. Various applied pulse shapes for the appearance of the transparent state.
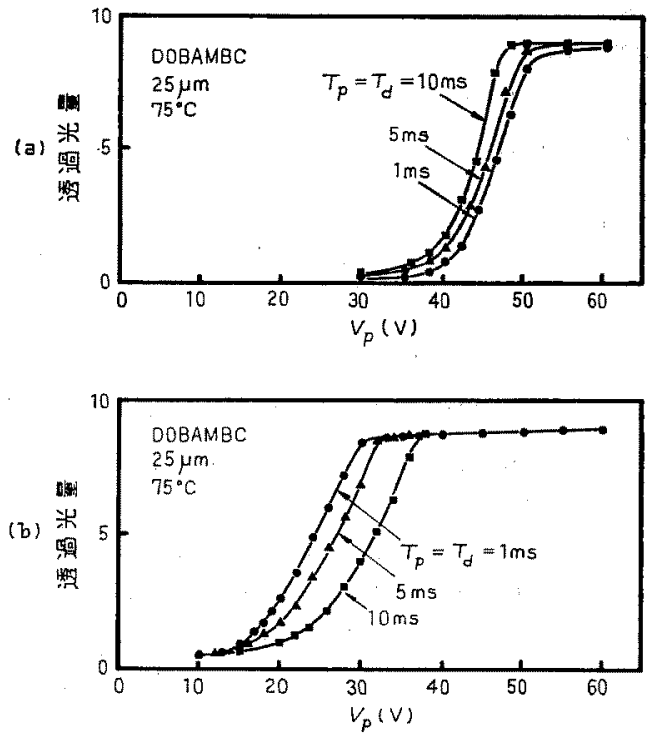

(a) 最初からパルス電代を印加した場合

(b) 予め直流バイアスを印加しておいた場合

図 19 DOBAMBC $25 \mu \mathrm{m}$ セルにおける 透過光量の電压依存性

Fig. 19. Voltage dependence of transmission through the $25 \mu \mathrm{m}$ cell of DOBAMBC under the application of pulse trains from the beginning (a) and D.C. bias voltage at first (b).

との逢いを示したのが図 19 である。図 19(a) は初 めからパルス電生駆動した場合の，パルス波高值 $V_{p}$ と透過光量との関係を示したるのである。この場合に は, パルス幅 $T_{p}=1 \mathrm{~ms}$, パルス間隔 $T_{d}=1 \mathrm{~ms}$ の きに，高光透過状態を実現するのに $50 \mathrm{~V}$ のパルス波 高値 $V_{p}$ を必要とする（直流電圧で高光透過状態を実 
現するにはこの場合 $15 \mathrm{~V}$ でよい\%。これに対して図 18(a) のように，あらかじめへリカル構造を解くの に十分な直流電圧（この場合 $60 \mathrm{~V}$ とした）を印加し て扰き，次にパルス波高值 $V_{p}\left(\mathrm{~V}_{p} \leqq 60 \mathrm{~V}\right)$ のパルス波 形に切り換えた場合のパルス波高值 $V_{p}$ 之透過光量之 の関係を因 $19(\mathrm{~b})$ に示す。これを見ると， $T_{p}=T_{d}=$ $1 \mathrm{~ms}$ のときに，パルス波高值 $V_{p}=30 \mathrm{~V}$ であ高光透 過状態を維持するととが可能である。すなわち，いっ たん直流電圧でへリカル構造を解いておけば, $P_{s} \cdot E$

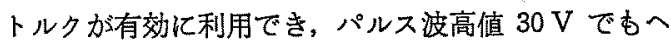
リカル構造の解けた高光透過状態が維持できている。

この他にも図 18(b) 亿示すように, 直流電圧の代 りにヘリカル構造を解くのに十分なパルス波高值 Vo を持つパルス波形を印加して高光透過状態を実現した 後に，その波高值を下げていった場合にあ高光透過状 態は維持できる。更に，図18(c)に示すように，へリ カル構造を解くのに十分なパルス幅 $T_{0}$ を持ったパル ス波形を印加して，いったん高叱透過状態を実現した 後，そのパルス幅を狭くしていった場合にあ，高光透 過状態は実現できる。以上に挙げた例のようなパルス による高光透過状態の維持では，直流電圧を印加して 高光透過状態を維持するよりも省電力での駆動が可能 である。

\section{4. まとめ}

以上の強誘電性液晶の電気光学効果に関する研究で 得られた結果をまとめると，次のようになる。

(1) TSM 形電気光学効果の立上り時間は, 数十〜 数百 $\mu \mathrm{s}$ 之極めて高速であり, その駆動力は $P_{s} \cdot E$ 卜 ルクに起因し， $T_{r} \sim \eta / P_{s} \cdot E$ の関係を満足している。

(2) コントラストは，数十以上之極妨大さく，七 ル厚が厚いほど大きな値となっている。しきい值電界 は，セル厚が厚いほど低く，壁面との影響が大きいと 思われる。

(3) TSM 形素子においては，液晶分子の配向度が 悪いほどコントラストは良く，また，応答時間への配 向度の影響はない。従って，TSM 形素子は，特殊な 配向処理を必要としない。

(4) 立下り時間は，高温，高電界任ど短くなってい る。また，誘電率の分散周波数の高い DOBA-1-MBC などでは極めて高速であり，七ル厚が薄い恬ど高速と なり，誘電率の緩和時間やへリカル構造の運動などの
複雑な要因を含んでいると考えられる。

(5) 高光透過状態を維持する際に，直流バイアス電 圧を印加する代りに，連続パルス電庄を用いるととが でき，実用面から極めて有効である。

これまでの結果から明らかなように，本論文で述へ たTSM 形素子は, 高速, 高コントラストという優れ た特性を示しており，液晶プリンタ，各種目的の眼鏡 シャッタ，表示素子を初め種々の分野に活用できるこ とがわかる。しが，との素子は，SSFLC 形素子と 連って，極めて薄いセルを用いる必要むなく，また， 配向のためのガラス表面の処理などに特別の工夫も不 要であり，セル製作という面からむ都合加良い。現象 としては，まだまだ末知の部分が多いが，分子構造に あ先に述べた特性が強く依存するので，更に自発分極 の大きい液晶，誘電緩和周波数の異なる液晶などを新 たに合成して研究を進めつつある。

本研究で用いた, DOBA-1-MPC, DOBA-1-MBC などについては，味の素(株)桜井孝男氏，本間正男氏 らの協力を得ているととを記し，謝意を表したい。

(昭和 60 年 8 月 30 日受付)

\section{文、献}

(1) R.B. Meyer, et al. : "Ferroelectric Liquid Crystal" J. Phys. (Paris) 36, L69 (1975)

(2) K. Yoshino, et al.: "Electro-Optical Effect in Ferroelectric Smectic Liquid Crystal" Jpn. J. Appl. Phys. 17, 597 (1978)

(3) N.A. Clark, et al.: "Submicrosecond Bistable ElectroOptic Switching in Liquid Crystals" Appl. Phys. Lett. 36. 899 (1980)

(4) K. Yoshino, et al.: "New Electro-Optic Effect of Microsecond Response Utilizing Transient Light Scattering in Ferroelectric Liquid Crystal" Jpn. J. Appl. Phys. 23, L 385 (1984)

(5) K. Yoshino, et al. : "Transient Light Scattering by Domain Switching in Ferroelectric Liquid Crystal and Its Application as Fast Opto-Electronics Device" Ferroelectrics 59,145 (1984)

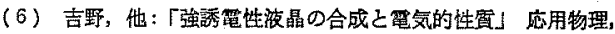
$49,876(1980)$

(7) T. Sakurai, et al. : "Synthesis and Ferroelectric Properties of New Series of Ferroelectric Liquid Crystal" Ferroelectrics $58,21(1984)$

(8) K. Yoshino, et al. : "Ferroelectric Liquid Crystal with Extremely Large Spontaneous Polarization" Jpn. J. Appl. Phys. 23, L 175 (1984)

(9) B.I. Ostrovski, et al.: "Ferroelectric Properties of Smectic Liquid Crystal, Ferroelectrics 20, 189 (1978)

(10) K. Kondo, et al.: "Preparation of Monodomain Cells of Ferroelectric Liquid Crystals and Their Evaluation with an Optical-Microscope" Jpn. J. Appl. Phys. 20, 1773 (1981) 